\title{
CONGENITAL PSEUDARTHROSIS OF THE CLAVICLE
}

Marina Juliana Pita Sassioto Silveira de Figueiredo', Susana dos Reis Braga², Miguel Akkari³ , José Carlos Lopes Prado, Cláudio Santili 5

\section{ABSTRACT}

Congenital pseudarthrosis of the clavicle (PCC) is a rare affection, that can be diagnosed at birth and represent a disturbance of union of the ossification centers. It's more common in girls and in the right side. This study objectives to proceed a revision about the subject, that was searched in online database of LILACS and MEDLINE. We found 56 articles till present data. Besides be a bit infrequent, the
PCC must not be missed or even forgotten, especially as differential diagnosis with acute fracture of the clavicle at birth by trauma in the childbirth. The diagnostic is relatively easy and the treatment can be just observation or even surgical.

Keywords - Clavicle; Pseudoarthrosis; Congenital Abnormalities

\section{INTRODUCTION}

The first description of congenital pseudarthrosis of the clavicle is attributed to Fitzwilliams ${ }^{(1)}(1910)$, and was included in a series of cases of cleidocranial dysostosis. The second known case was reported by Owen $^{(2)}$ in 1930. Today, there are just over 200 descriptions in the literature ${ }^{(3-9)}$.

The majority of these cases have affected the right clavicle in girls $^{(7-11)}$. Congenital pseudarthrosis of the left clavicle, which is present in less than $10 \%$ of the cases $^{(12)}$, is associated with other congenital disorders such as dextrocardia. It is generally observed contralaterally to the heart ${ }^{(8,10,13,15)}$.

Its etiology remains unknown despite many investigations $^{(8,11,16)}$, but it is known to be associated with abnormalities of ossification during embryogenesis ${ }^{(7,8,14)}$.

Clinically, congenital pseudarthrosis of the clavicle is perceived just after birth or during the first days of life, as a painless protuberance at the level of the middle third and more laterally ${ }^{(3,8,16,19)}$.
The deformity tends to become more obvious as the child grows. The skin on the protuberance may become thin and atrophic ${ }^{(3,7,10,14,20)}$.

\section{METHODOLOGY}

This topic was investigated in the LILACS and MEDLINE databases using the descriptors pseudarthrosis, congenital and clavicle. We found 56 articles published up to December 2010, of which 24 were single-case reports, 16 were case series reports and the remainder were review articles.

\section{REVIEW OF THE LITERATURE}

\section{Concept}

Congenital pseudarthrosis of the clavicle is a rare disorder that is diagnosed at birth and triggered by failure of the union process of the ossification nuclei of the clavicle. Its etiology is unknown ${ }^{(3,21,23)}$.

1 - Ortopedist, Former Intern of the Pediatric Orthopedics and Traumatology Group of the Irmandade Santa Casa de Misericódia de São Paulo (ISCMSP) - São Paulo, SP, Brazil.

2 - Master's Degree in Orthopedics, Assistent of the Pediatric Orthopedics and Traumatology Group of the Irmandade Santa Casa de Misericódia de São Paulo (ISCMSP) São Paulo, SP, Brazil.

3 - PhD in Health Sciences, Head of the Pediatric Orthopedics and Traumatology Group of the Irmandade Santa Casa de Misericódia de São Paulo (ISCMSP) - São Paulo, SP, Brazil.

4 - Full Professor, Assistent of the Pediatric Orthopedics and Traumatology Group of the Irmandade Santa Casa de Misericódia de São Paulo (ISCMSP) - São Paulo, SP, Brazil.

5 - Assistant Professor of the Faculty of Medical Sciences of the ISCMSP, Senior Doctor of the Pediatric Orthopedics and Traumatology Group of the Irmandade Santa Casa de Misericódia de São Paulo (ISCMSP) - São Paulo, SP, Brazil.

Work carried out at the Irmandade Santa Casa de Misericódia de São Paulo (ISCMSP), São Paulo, SP.

Correspondence: Cláudio Santili Rua Mato Grosso 306 conj 1212, Higienópolis. São Paulo - SP E-mail: ortopediatrica@yahoo.com.br.

Received for publication: 08/03/2011, accepted for publication: 09/24/2011

The authors declare that there was no conflict of interest in conducting this work 


\section{Embryology}

The clavicle arises from a cartilage mold derived from mesenchymal cells, at the stage at which the embryo length is $11 \mathrm{~mm}$, and it divides into two pre-cartilage masses at the stage of $15 \mathrm{~mm}$. At the embryonic stage of $17 \mathrm{~mm}$, the ossification centers can be clearly seen. These are the Fawcett stages ${ }^{(23)}$ (Figure 1). At the stage of $18-19 \mathrm{~mm}$, the horizontal sections of the clavicle show the bone masses separated by a pre-cartilaginous interval, surround by perichondrium, which under normal ossification conditions will produce union between the two cartilaginous centers.

In the fourth week of gestation, the clavicle has a length of approximately $11 \mathrm{~mm}$, and is the first bone of the skeleton to become ossified ${ }^{(7,8,23)}$. Fusion of the two ossification centers occurs around the seventh week ${ }^{(3,5,8)}$.

\section{Epidemiology}

The right clavicle in girls is more often affect$\mathrm{ed}^{(5,8,11,21)}$, accounting for around $80 \%$ of the cases ${ }^{(13)}$.

Congenital pseudarthrosis of the left clavicle is associated with other congenital disorders, such as dextrocardia ${ }^{(8,10,12,14,15)}$.

Bilateral involvement may occur in up to $10 \%$ of the cases and is associated with an abnormally high position for the subclavian artery, caused by the presence of cervical ribs or vertical turning of the upper ribs ${ }^{(5,8,16,21)}$.

Syndromes associated with congenital pseudarthrosis of the clavicle include Ehlers-Danlos ${ }^{(25)}$, Al-
I.
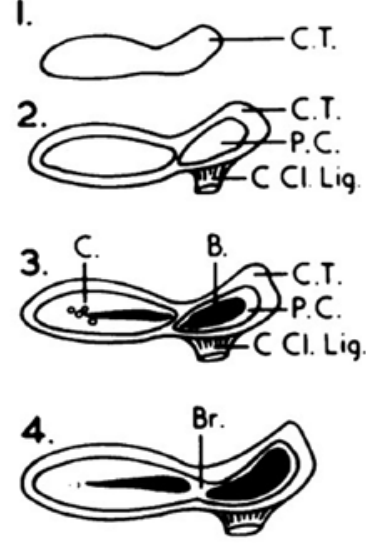

5.
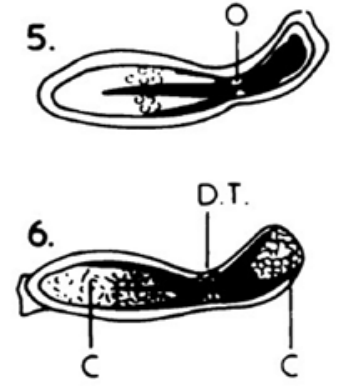

Figure 1 - Diagrams showing development of the right clavicle, according to Fawcett's stages. CT: connective tissue; PC: precartilage; CCI Lig: costoclavicular ligament; C: calcified cartilage; B: bone; Br: bridge; O: ossification; DT: dense tissue. Source: Fawcett. J Anato Physiol. 1913:47(PT2):225-34.
Awadi/Ras-Rothschild ${ }^{(26)}$ (aplasia/hypoplasia of the pelvis/lower limbs), Kabuki ${ }^{(27,28)}$ (short stature, musculoskeletal and cutaneous abnormalities, moderate mental retardation and facial dysmorphism) and Prader-Willi(29). Associated occurrences of thoracic outlet syndrome and cases with multiple vertebral abnormalities have also been described ${ }^{(30,31)}$.

In the present review, there were 158 patients, of whom $57.5 \%$ were female and $42.5 \%$ were male. The right side was affected in $92.6 \%, 4.4 \%$ were bilateral and the left side was affected in $3 \%$, but without reports of any association with dextrocardia. The mean age at diagnosis was three years and two months. The commonest complaint was painless tumefaction $(39.5 \%)$. Nine cases presented pain of varying intensity, discomfort or functional limitation of the limb at the time of seeking medical care.

In most cases, there were no reports of any family members similarly affected. A family history was present in nine of the 58 cases investigated. In four cases, the occurrences were in sisters ${ }^{(32)}$; in one, the father ${ }^{(33)}$; in one, the mother and two sisters ${ }^{(34)}$; and in the other three, the degree of kinship was not mentioned $^{(35,36)}$.

\section{Etiopathogenesis}

There have been a variety of etiological theories, but all of them relate to disorders of ossification during embryogenesis ${ }^{(3,7,8,11,14,16)}$.

The development of the clavicle from two precartilaginous centers that evolve to ossification was recognized by $\mathrm{Mall}^{(37)}$, in 1906, in the embryonic stage of $15 \mathrm{~mm}$. Failure of these to nuclei to coalesce is the factor responsible for the appearance of pseud$\operatorname{arthrosis}^{(5,21,38)}$.

According to some authors ${ }^{(8,14,18,39)}$, excessive pressure exerted by pulsation of the subclavian artery during the process of development of the clavicle may cause the ossification centers to fail to unite, especially when associated with presence of a cervical rib.

Other causal hypotheses have made associations with situations in which the right subclavian artery is at a higher position than the contralateral one ${ }^{(8)}$ and abnormal intrauterine positions taken up by the fetus ${ }^{(8,16)}$, but without subsequent confirmation.

Since some family cases have been reported, this suggests that there is a possible pattern of dominant autosomal inheritance ${ }^{(5,7,8,21)}$. 


\section{Natural history}

The natural history of congenital pseudarthrosis of the clavicle in untreated cases is not fully known. We evaluated this condition in cases in which it was only observed without any surgical treatment $^{(13,17,19,31,32,40,42)}$. In addition, a report by Shalom et $\mathrm{al}^{(39)}$, in 1994, described a 45 -year-old man with congenital pseudarthrosis of the right clavicle that had been diagnosed during childhood, without any other abnormalities, and none in members of his family. Upon examination, he presented a protuberance in the right-side medial clavicular region, which was painless on palpation and in movement. He presented free shoulder mobility, over the complete range. There was no hypotrophy or loss of muscle strength. The radiographs confirmed the presence of mobile pseudarthrosis, without arthrotic abnormalities in the acromioclavicular joint. The patient refused treatment because he accepted the deformity and did not have any functional loss.

The evolution of these cases shows that consolidation does not occur spontaneously, but functional loss practically does not exist and there is only the esthetic deformity.

However, it was observed that the natural evolution of most of the cases was halted through the surgical approach. The indications for surgery were mainly due to the esthetic impairment, while in other cases they were due to progressive pain, functional limitation, late-starting thoracic outlet syndrome, or a combination of these factors.

\section{DIAGNOSIS}

The clinical diagnosis is made through observation of the painless protuberance in the middle third of the clavicle and a hypermobile segment at birth or during the first days of life $\mathrm{s}^{(3,5,7,8,16,18,19,21,39,43,55)}$.

The deformity tends to become more obvious with the child's growth, since it is associated with shortening and "drooping" of the scapular belt (3,7-10,14,15,18-21) $^{(2)}$ The esthetic aspect is more important when girls are $\operatorname{affected}^{(3)}$.

Pseudarthrosis may become painful with some activities that involve movements above head level or with direct compression of the focus. Shoulder movements are normal and functional incapacity does not occur as a rule ${ }^{(21)}$.

The skin over the protuberance may become thin and atrophic ${ }^{(3,8,16)}$ and the tumefaction of the focus of the pseudarthrosis becomes more accentuated when the patient raises the upper limb (Figure 2).

Radiographs are necessary for the diagnosis. The radiographic findings are characteristic and include clear separation in the middle portion, with the medial fragment positioned above the lateral fragment because of the action of muscle forces and the postural traction exerted by the weight of the upper limb. The lateral extremity is voluminous and medial extremity is atrophic, with sclerotic closure of the medullary canal and without formation of a reactional bone callus ${ }^{(21)}$ (Figure 2).

Differential diagnoses should be made. The diagnosis of acute fracturing of the clavicle at birth is ruled out by the absence of obstetric trauma and absence of pain or irritability when the child is touched, and by the lack of excessive callus produced in the immediate evolution. The diagnosis of cleidocranial dysplasia is ruled out by the absence of radiographic appearance characteristic of a clavicular defect and absence of other malformations characteristic of the cranium and pelvis ${ }^{(3,5,21,30,39)}$. The diagnosis of neurofibromatosis is ruled out especially by the absence of "milky coffee" skin stains ${ }^{(3,5,22)}$.

Some cases of scalene syndrome and thoracic outlet syndrome have been described in association with congenital pseudarthrosis of the clavicle ${ }^{(22,41)}$.

\section{Classification}

In 1968, Kite $^{(42)}$ suggested a classification system for congenital pseudarthrosis of the clavicle based on anatomical, clinical and pathological differences, with implications for treatment indications:

I: Congenital failure of two segments of the clavicle to unite. This is seen at birth, and occurs because of hypoplasia of the distal fragment of the clavicle. Pressure on the prominence causes pain. On radiographs, the medial fragment is bigger than the lateral fragment, and the space between the fragments is evident. Surgical treatment should not be indicated.

II: Congenital bone deficiency. Like in cases of congenital pseudarthrosis of the tibia, the clavicle is seen at birth to have formed normally and fractures with the slightest trauma. In these cases, surgical treatment may be indicated. This is the form that presents a better prognosis.

\section{Histopathology}

In anatomopathological specimens, the foci of the pseudarthrosis are characterized by the presence of 


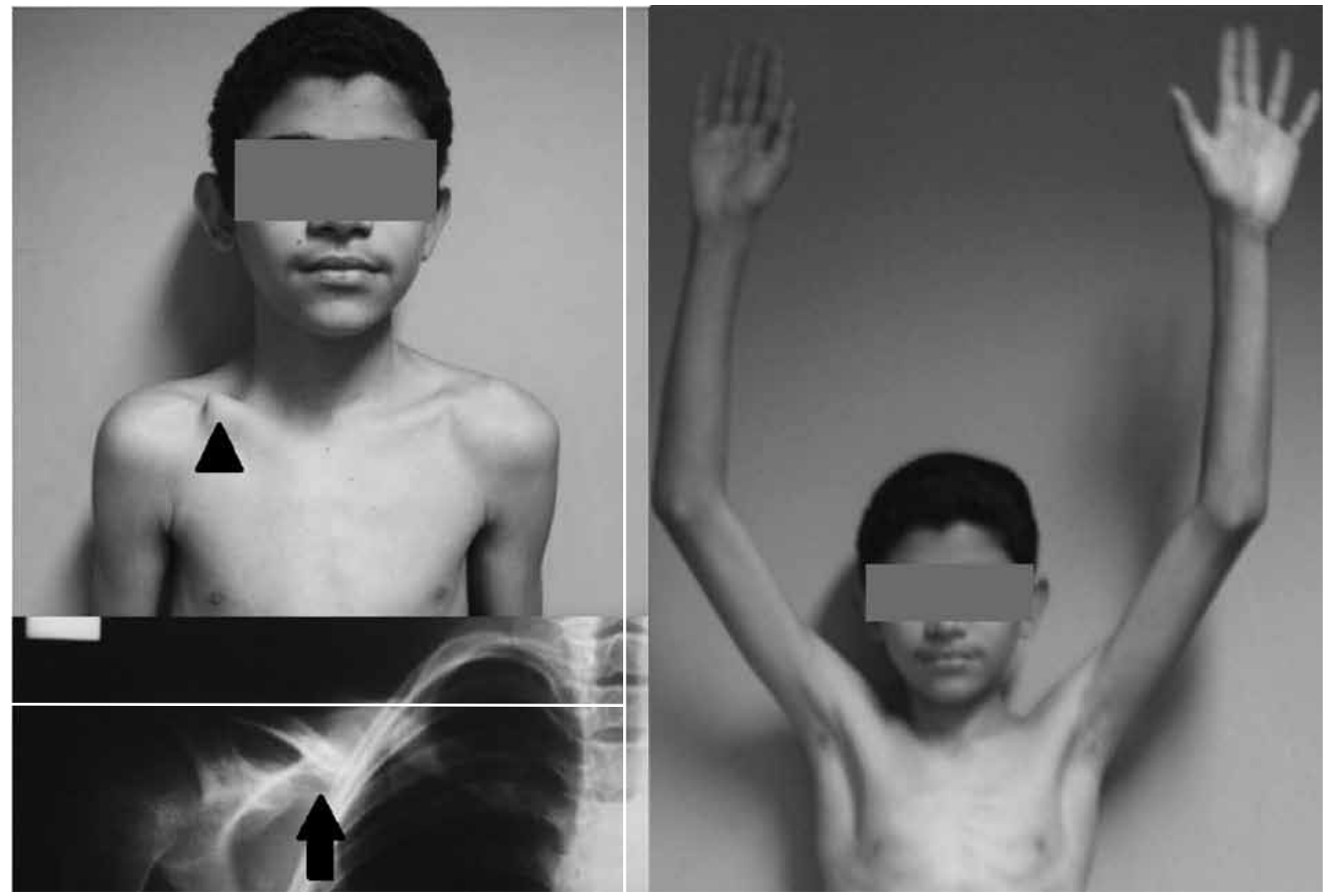

Figure 2 - Thirteen-year-old male patient with congenital psєudarthrosis of the right clavicle. Note the protuberance in the topographical region of the middle third of the right clavicle (red aırow) and normal range of motion. Radiograph showing the atrophic medial fragment positioned above the lateral fragment, and without formation of a bone callus (black arrow).

hypertrophic bone tissue surrounded by hyaline cartilaginous covers at both extremities. They are reminiscent of "elephant's foot" pseudarthrosis, connected by dense fibrous and fibrocartilaginous tissue, without evidence of osteoblast or chondrocyte activity. The fibroblasts are mature cells with pyknotic nuclei, located below the cartilaginous zone. Chondrocytes are seen at different stages of maturation, which is related especially to the patient's age, i.e. more differentiated with greater maturity ${ }^{(3,43)}$.

It is important to emphasize that the clavicle is a bone that presents intramembranous ossification in the pre-cartilaginous portion and endochondral ossification for longitudinal growth at the extremities, in the same way as in the long bones. Hirata et $\mathrm{al}^{(18)}$ demonstrated that the chondrocytes at different stages of maturation of the extremities of the pseudarthrosis presented a columnar layout, similar to the patterns seen in epiphyseal growth plates. The endochondral ossification at these extremities was confirmed and mapped by means of marker impregnation using tetracycline ${ }^{(20)}$.

\section{TREATMENT}

Most of the cases reported underwent some type of surgical intervention. As reported earlier, the indications for operative treatment were: progressive pain, esthetic deformity, functional limitation and late-starting thoracic outlet syndrome ${ }^{(37,42)}$.

Many authors recommended that surgery should be delayed until the patient was between three and six years of age. At that age, resection of the focus of the pseudoarthrosis was indicated, with or without associated bone grafting and fixation ${ }^{(3,6,9,12,21,32,40,44,52,54,56,57)}$.

Dzupa et $\mathrm{al}^{(6)}$ reported occurences of clavicular fractures 20 months after removal of the synthesis (semitubular plate) that had been used to treat the congenital pseudarthrosis of the clavicle. Fracturing occurred along the line of one of the holes drilled to locate the screw. This was then treated using a figureof-eight dressing, and complete consolidation was achieved.

In analyzing the 124 cases reported in this review (mean follow-up of 4.58 years), we only took into consideration the cases for which a description of the type of treatment used was available. We found that 
40 patients were only kept under observation and five underwent resection of the focus of the pseudarthrosis alone. Four cases underwent resection of the focus of the pseudarthrosis and placement of a graft, without stabilization by means of osteosynthesis. Six cases underwent resection of the focus of the pseudarthrosis and fixation with synthesis using an intramedullary wire (either smooth or threaded), without graft placement. In 47 cases, an intramedullary wire was used with a bone graft. A plate and screws was used together with grafting in 19 cases. Lastly, a plate and screws without grafting, crossed smooth wires and external fixation was used in one case each.

All the cases operated with grafting evolved to bone consolidation. In the cases in which resection was performed, with or without synthesis, consolidation was achieved in those in which the space between the fragments was small and had complete periosteum. The time taken to achieve this consolidation was not evaluated.

It is important to bear in mind that patients will exchange a protuberance for a scar, given that the majority of the indications for surgical treatment are for esthetic reasons.

Postoperative immobilization consisting of thoracic-brachial containment using a Velpeau sling $(19,22,41)$ or Desault bandage ${ }^{(6,45)}$ for four ${ }^{(6,22,45)}$ to six weeks ${ }^{(46)}$.

Few complications have been described. In two cases, the synthesis material failed; in one case, pain and weakness in the operated limb were reported; in one case, there was hypotrophy of the operated limb; and in one case that had been treated with an intramedullary wire, consolidation did not occur and a new approach became necessary. There was one report of superficial infection and one of neuropraxia of the brachial plexus, with subsequent complete recovery.

\section{FINAL REMARKS}

Congenital pseudarthrosis of the clavicle is a rare condition and it can be supposed that orthopedists might only be faced with two or three such cases during their lives. Nonetheless, they should be ready to make the diagnosis and provide appropriate care.

Its pathogenesis remains unclear, but all the theories corroborate the idea that fusion of the ossification nuclei of the clavicle is absent.

The initial diagnosis is relatively easy, but some of these children appear with a history of previous trauma or are newly born from complicated deliveries. This condition needs to be differentiated from fractures due to neonatal birth injuries or, at school age, from cleidocranial dysostosis or other syndromes that are associated with congenital pseudarthrosis of the clavicle, such as Ehlers-Danlos, Al-Awadi/RasRothschild and Kabuki.

The range of motion in these children is practically normal and totally free from pain. What disturbs the most is the esthetic deformity, which appears most during movement and usually becomes unacceptable to the parents.

Confirmation of the diagnosis of congenital pseudarthrosis of the clavicle is obtained from simple radiographs, on which one extremity presents an "elephant's foot" shape and the other has a "pencil point" shape, without contact between them and without any formation of a reactional bone callus.

The treatment for this type of pseudarthrosis is a matter for debate, since some authors have chosen to keep the case under observation, others have chosen resection alone and still others have chosen operative treatment with or without bone grafting.

In cases of congenital pseudarthrosis of the clavicle of Kite type II, observation is without doubt the best option. However, in type I cases, it is prudent to assess the distance between and positioning of the fragments, since separation greater than $1 \mathrm{~cm}$ and large displacements of the fragments make the operative procedure difficult. In such cases, there is also a need for large quantities of graft material, as well as larger plates for synthesis. The material is likely to be under tension, which implies the risk of material failure and non-consolidation of the pseudarthrosis.

It is always good to ensure that the patient or his/ her parents is aware that the tumefaction will be exchanged for a scar that could become hypertrophic, form keloid or remain painful, as well as possible scarring of the donor site, when autologous bone grafts have to be used.

In cases in which operative treatment is chosen, explanations regarding the need to use some type of synthesis material for fixation of the foci and graft removal, if this is the case, should be given to the patient and parents.

The type of fixation used also varies in the literature. This can be done using external fixation, plates and screws, screws alone, Kirschner wires or Steinmann intramedullary pins.

Grafting is optional. In the studies analyzed in this review, all the cases in which bone grafts were used achieved consolidation. The graft most used was from 
the iliac crest, but there were also reports of grafts taken from the tibia and ribs, and vascularized grafts from the fibula. Operative treatment succeeds best among children aged two to four years and these patients have the highest chance of achieving consolida-

\section{REFERENCES}

1. Fitzwilliams D. Hereditary cranio-cleido-dysostosis. Lancet 1910;2:1466.

2. Owen R. Congenital pseudarthrosis of the clavicle. J Bone Joint Surg Br. 1970;52(4):644-52.

3. Saint-Pierre L. Pseudarthrose congénitale de la clavicule droite. Ann d'Anatom Pathotol d'Anatom Normal Med-Chir. 1930;7:625.

4. Behringer BR, Wilson FC. Congenital pseudarthrosis of the clavicle. Am J Dis Child. 1972;123(5):511-7.

5. Manashil G, Laufer S. Congenital pseudarthrosis of the clavicle: report of three cases. AJR Am J Roentgenol. 1979;132(4):678-9.

6. Dzupa V, Bartonicek J, Zidka M. Fracture of the clavicle after surgical treatment for congenital pseudarthrosis. Med Sci Monit. 2004;10(1):CS1-4.

7. Gibson DA, Carroll N. Congenital pseudarthrosis of the clavicle. J Bone Joint Surg Br. 1970;52(4):629-43.

8. Beslikas TA, Dadoukis DJ, Gigis IP, Nenopoulos SP, Christoforides JE. Congenital pseudarthrosis of the clavicle: a case report. $\mathrm{j}$ Orthop Surg (Hong Kong). 2007;15(1):87-90.

9. Cadilhac C, Fenoll B, Peretti A, Padovani JP, Pouliquen JC, Rigault P. [Congenital pseudarthrosis of the clavicle: 25 childhood cases]. Rev Chir Orthop Reparatrice Appar Mot. 2000;86(6):575-80.

10. Sharrard WJ. Pediatric orthopaedics and fractures. Oxford. Blackwell Scientific Publications; 1979. p.277-80.

11. Kumar R, Madewell JE, Swischuk LE, Lindell MM, David R. The clavicle: normal and abnormal. Radiographics. 1989;9(4):677-706.

12. Amador EV, Villamarín FG, Quintero MP. Pseudoartrosis congénita de clavícula patología de alta confusión diagnóstica. Rev Facul Med Univer Nac Colomb. 2006;54(3):206-10.

13. Quinlan WR, Brady PG, Regan BF. Congenital pseudarthrosis of the clavicle. Acta Orthop Scand. 1980;51(3):489-92.

14. Lloyd-Roberts GC, Apley AG, Owen R. Reflections upon the aetiology of congenital pseudarthrosis of the clavicle. With a note on cranio-cleido dysostosis. J Bone Joint Surg Br. 1975;57(1):24-9.

15. Lloyd-Roberts GC, Fixsen JA. Congenital pseudarthrosis of the clavicle. In: Canale ST. Orthopaedics in infancy and childhood. London: Butterworth-Heinemann; 1989. p.94-5.

16. Herring JA. Pseudarthrosis of the clavicle. In: Tachdjian's pediatrics orthopaedics. 4th ed. Philadelphia: WB Saunders; 2008. p. 2423-9.

17. Padua R, Romanini E, Conti C, Padua L, Serra F. Bilateral congenital pseudarthrosis of the clavicle report of a case with clinical, radiological and neurophysiological evaluation. Acta Orthop Belg. 1999;65(3):372-5.

18. Hirata S, Miya H, Mizuno K. Congenital pseudarthrosis of the clavicle. Histologic examination for the etiology of the disease. Clin Orthop Relat Res.1995;(315):242-5.

19. Lorente Molto FJ, Bonete Lluch DJ, Garrido IM. Congenital pseudarthrosis of the clavicle: a proposal for early surgical treatment. J Pediatr Orthop. 2001;21(5):689-93.

20. Beaty JH. Congenital pseudarthrosis of the clavicle. In: Canale ST. Campbell's operative orthopaedics. Philadelphia: Mosby; 2003. p.1132-3.

21. Price CT, Phillips JH, Devito DP. Pseudartrose congênita da clavícula. In: Ortopedia pediátrica de Lovell e Winter. In: Morrissy RT, Weinstein SL. Philadelphia: Lippincott Wiliams \& Wilkins; 2005. p.387-9

22. Carpenter EB, Garrett RG. Congenital pseudarthrosis of the clavicle: Report of a case with resection and bone-grafting. J Bone Joint Surg Am. 1960;42:337-40.

23. Jinkins WJ Jr. Congenital pseudarthrosis of the clavicle. Clin Orthop Relat Res. 1969;62:183-6.

24. Fawcett. The Development and Ossification of the Human Clavicle. J Anat Physiol. 1913;47(Pt 2):225-34.

25. Colavita N, La Vecchia G, Book E, Vincenzoni M. [Congenital pseudarthrosis of the clavicle: roentgenographic appearance and discussion of the aetiological and pathogenetical theories [author's transl]. Radiol Med. 1980;66(12):923-6.

26. Camera G, Ferraiolo G, Leo D, Spaziale A, Pozzolo S. Limb/pelvis-hypoplasia/ aplasia syndrome (Al-Awadi/Raas-Rothschild syndrome): report of two Italian sibs and further confirmation of autosomal recessive inheritance. J Med Genet. 1993;30(1):65-9.

27. Turner C, Lachlan K, Amerasinghe N, Hodgkins $P$, Maloney V, Barber J, et al. Kabuki syndrome: new ocular findings but no evidence of 8p22-p23.1 duplications in a clinically defined cohort. Eur J Hum Genet. 2005;13(6):716-20. tion. The age for surgical treatment is very variable. In most cases, it is indicated at between two and six years of age, but some authors have performed surgery on younger children, of 19 months. Bone grafts must be used in children over the age of eight years.

28. Genevieve D, Amiel J, Le Merer M. Sanlaville D, Urtizberea A, Gerard M, et al.. Atypical findings in Kabuki syndrome: report of 8 patients in a series of 20 and review of the literature. Am J Med Genet A. 2004;129A(1):64-8.

29. Sponer P, Neumann D, Karpas K. [Congenital pseudoarthrosis of the clavicle in a boy with Prader-Willi's syndrome]. Acta Chir Orthop Traumatol Cech. 2008;75(2):134-6.

30. Wall JJ. Congenital pseudarthrosis of the clavicle. J Bone Joint Surg Am.1970;52(5):1003-9.

31. Ahmadi B, Steel HH. Congenital pseudarthrosis of the clavicle. Clin Orthop Relat Res. 1977;(126):129-34.

32. Alldred AJ. Congenital pseudarthrosis of the clavicle. J Bone Joint Surg Br. 1963;45-B:312-9.

33. Price BD, Price CT. Familial congenital pseudoarthrosis of the clavicle: case report and literature review. lowa Orthop J. 1996;16:153-6.

34. Toledo LC, MacEwen GD. Severe complication of surgical treatment of congenital pseudarthrosis of the clavicle. Clin Orthop Relat Res. 1979;(139):64-7.

35. SHIM JS, CHANG MJ. Congenital pseudarthrosis of the clavicle - report of 4 cases treated with surgical methods. J Korean Orthop Assoc 2008;43:396-9.

36. Persiani P, Molayem I, Villani C, Cadilhac C, Glorion C. Surgical treatment of congenital pseudarthrosis of the clavicle: a report on 17 cases. Acta Orthop Belg. 2008;74(2):161-6.

37. Mall FP. Ossification centers in human embryos less than one hundred days old. Am J Anat 1906;5:433-58.

38. Ogata S, Uhthoff HK. The early development and ossification of the human clavicle--an embryologic study. Acta Orthop Scand. 1990;61(4):330-4.

39. Shalom A, Khermosh O, Wientroub S. The natural history of congenital pseudarthrosis of the clavicle. J Bone Joint Surg Br. 1994;76(5):846-7.

40. Moral VF, Vigil AB, Muñiz MLC, Vigil AB. Pseudartrosis congénita de clavícula. A propósito de um caso. Rev Esp Cir Osteoart. 1993;28:51-3.

41. Rodrígruez JR, Martínez A, Carbonell C. Pseudartrosis congénita de clavícula asociada a síndrome del estrecho torácico superior. Presentación de um caso y revisión de la literatura. Rev Esp Cir Osteoart. 1997;32:220-4.

42. Kite JH. Congenital pseudarthrosis of the clavicle. South Med J. 1968;61(7):703-10.

43. Gomez-Brouchet A, Sales de Gauzy J, Accadbled F, Abid A, Delisle MB, Cahuzac JP. Congenital pseudarthrosis of the clavicle: a histopathological study in five patients. J Pediatr Orthop B. 2004;13(6):399-401.

44. Bartolozzi P, Bonometto L, Sandri A, Pezzè L, Marino M, Carità E. La pseudoartrosi congenita di clavicola: un caso clinico a sei anni dall'intervento e revisione della letteratura. Giornale Ita Ortop Traumatol. 2005;31:30-1.

45. Pina ERM, Carvalho PCC, Bernardino C, Oliveira RH. Pseudartrose congênita da clavícula: relato de caso. Rev Mineira Ortop Traumatol. 2004;2(4):37-42.

46. Brighton CT, Friedenberg ZB, Zemsky LM, Pollis PR. Direct-current stimulation of non-union and congenital pseudarthrosis. Exploration of its clinical application. J Bone Joint Surg Am. 1975;57(3):368-77.

47. Glotzbecker MP, Shin EK, Chen NC, Labow BI, Waters PM. Salvage reconstruction of congenital pseudarthrosis of the clavicle with vascularized fibular graft after failed operative treatment: a case report. J Pediatr Orthop. 2009;29(4):411-5.

48. Göktay AY, Seçil M, Çetünkol E, Özaksoy D. Congenital pseudoarthrosis of the clavicle with multiple vertebral anomalies. Turkish J Med Sci. 2002;32:77-9.

49. Güneş T, Erdem M, Sen C. [A case of congenital pseudarthrosis of the clavicle]. Acta Orthop Traumatol Turc. 2005;39(3):266-9.

50. Hacihasano O, Yed A, Davuto G, Mutlu N, Güzelta A, Adal A, Aldem H. Bilateral Konjenital Klavikula Psödoartrozu. stanbul Tıp Dergis. 2004;1:51-2.

51. Jenzi M, Bouaziz M, Hadidene R, Daghfous S, Jaafoura $H$, Zouari O. Une tumefactión de la clavicule droite chez un efant. Tunisie Orthop. 2008;1(1):95-7.

52. Maldonado EH, Cock PR. Pseudoartrosis congénita de la clavícula. Reporte de un caso. Rev Colomb Ortop Traumatol. 2006;20(3):65-7.

53. Marmor L. Repair of congenital pseudarthrosis of the clavicle. Clin Orthop Relat Res. 1966;46:111-3.

54. Muradas RR, Sévero MD, Silveira JOF, Tierno SA, Salame M, Pomblum VJ. Pseudartrose congênita da clavícula. Rev AMRIGS. 2009;53(4):410-2.

55. Rizzi Junior CB, Amorim RM, Cócaro TA. Pseudartrose congênita da clavícula: relato de caso. Ortop Trauma. 2008;5:5-7.

56. Sakellarides H. Pseudarthrosis of the clavicle. J Bone Joint Surg. 1961;43:130.

57. Sloan A, Paton R. Congenital pseudarthrosis of the clavicle: the role of CTscanning. Acta Orthop Belg. 2006;72(3):356-8. 